\title{
PENINGKATAN MUTU PENDIDIKAN POLITIK PEREMPUAN BALI MENUJU TERWUJUDNYA KESETARAAN GENDER
}

\author{
Oleh \\ I Gede Sudiarta \\ SMAN 1 Baturiti Tabanan \\ dagets@ymail.com
}

diterima 12 Oktober 2018, direvisi 18 Februari 2019, diterbitkan 28 Februari 2019

\begin{abstract}
General description of women's participation in the political world in Indonesia representation is very low at all levels of decision making, both at the executive, legislative and judicial levels in the government bureaucracy, political parties both in other public societies. In this case the low quality of women's participation in politics occurs in Bali, namely in the executive ranks. Likewise, at the echelon II level, there were no women who obtained the position, that is, from the number of village heads in Bali there were no women who held more positions as lurah, even if there were only a few. In addition, in the organization of the Lembaga Pemberdayaan Masyarakat (LPM) in Bali, it is rare and there may not be women who become the Bendesa Adat or Bendesa Pakraman. This is also evident in the management of other organizations such as youth clubs and sekuna teruna. In an organization like this it is rare to find women becoming chairpersons or electing a chairperson as chairman or vice chairman. Based on this, a gender perspective is considered by involving men and women in the basic decision-making process of democratic work that will lead to equality.
\end{abstract}

\section{Keywords: Pendidikan, Politik, Perempuan Bali, Kesetaraan Gender}

\section{PENDAHULUAN}

Penduduk, termasuk didalamnya kaum perempuan adalah salah satu modal dasar pembangunan nasional. Tanpa mengikutsertakan kaum perempuan dalam proses pembangunan bangsa dan Negara berarti lebih dari setengah jumlah penduduk Indonesia tidak tertampung aspirasinya dalam pembangunan bangsa dan Negara.
Salah satu contoh konkret pada pemilu 1999 yang lalu. Berdasarkan hasil penelitian Asia Foundation (Suryanef, 2001:46) menjelaskan bahwa di Indonesia terdapat pemilih perempuan sejumlah 57\% dar keseluruhan pemilih terdaftar. Hal ini adalah merupakan sebuah potensi dan kekuatan besar yang perlu disadari oleh perempuan, karena keberhasilan sebuah peristiwa politik, seperti 
pemilihan umum, sangatlah ditentukan oleh partisifasi perempuan. Berdasarkan UndangUndang Dasar 1945 Pasal 27 ayat 1 yang dipertegas di dalam GBHN dapat dinyatakan bahwa perempuan bagai mitra sejajar pria mempunyai peluang dan kesempatan yang sama dengan pria untuk berprestasi melakukan suatu kegiatandalam segala aspek pembangunan bangsa dan Negara. Selain itu sebagai warga Negara Indonesia perempuan mempunyaai hak dan kewajiban yang sama dengan laki-laki untuk dipilih dan atau memilih.

Dunia politik merupakan domain public yang diidentikkan dengan dunia lakilaki. Sementara, perempuan tidak mungkin menjadi actor dalam politik karena kepentingan mereka terbatas pada domain domestic atau urusan rumah tangga. Definisi kekuasaan seperti yang dijelaskan oleh Spike Peterson dan Anne Sisson Ruyan dalam "Global Gender Issues" (Kompas, 25 Agustus 2003) adalah maskulinis. Hal ini merupakan perpanjangan dari nation androcentric mengenai kekuatan, kompetensi agresi, dan koersi, oleh karena hanya memfokuskan pada pengertian mengenai kekuasaan di bidang politik yang didominasi oleh laki-laki. Dalam hal ini apabila pengertian ini diyakini, maka isu-isu kesejahteraan tampaknya akan sulit mendapat tempat. Oleh karena adanya dikotomi antara politik 'tinggi' dan politik "rendah" yang menenmpatkan kegiatan ruang public sebagai politik "tinggi" dan isuisu dianggap berkaitan dengan sector domestic, seperti isu kesejahteraan, sebagi politik "rendah'.

Secara fungsional pemilihaan peran laki-laki dan perempuan dapat diterima asalkan tidak menimbulkan ketimpangan gender, khususnya ketidaksetaraan gender. Ketidak setaraan gender yang dilakukan oleh orang tua dan keluarga, yakni dengan mengalahkan anak perempuan dalam hal bersekolah, makanan, kesehatan, dan pemberian tanggung jawab yang lebih besar daripada laki-laki. Sejalan dengan perkembangan dan dinamisasi masyarakat Bali sebagai implikasi dari interaksi dengan masyarakat luar, maka upaya pendidikan dan kesadaran politik pada kaun perempuan di Bali merupakan suatu keharusan. Berkaitan dengan hal tersebut, maka dalam makalah ini akan diupayakan untuk membahas prose pendidikan politik perempuan Bali dalam rangka menuju terwujudnya kesetaraan gender perspektif agama. Oleh karena itu pendidikan politik sejak dini pada perempuan dalam keluarga sudah seharusnya diterapkan sehingga perempuan dan laki-laki dapat setara dalam segala aspek kehidupan. Selain itu dengan banyaknya perempuan yang duduk dalam pengambilan keputusan dan kebijakan maka masalah-masalah seperti kekerasan terhadap perempuan dan anak serta kesehatan reproduksi dapat dipecahkan.

\section{PEMBAHASAN \\ A. Cara Pendidikan Politik Perempuan Bali}

Keikutsertaan kaum perempuan dalam aspek kehidupan manusia di dunia ini tidak dapat diabaikan. Di samping sebagai ibu dan peran kodrati lainnya yang dimiliki oleh perempuan, pada zaman globalisasi ini kehidupan kaum perempuan semakin berkembang dalam segala bidang kehidupan. Keikutsertaan kaum perempuan di Indonesia pada masa perang kemerdekaan, bahkan jauh sebum itu, setidak-tidaknya membawa perubahan dalam perkembangan kehidupan bangsa Indonesia. Bahkan diakui bahwa tanpa keikutsertaan perempuan, perjuangan tidak mungkin akan berhasil denganbaik. Hal ini sejalan dengan kenyataan bahwa dalam perjuangan, mau tidak mau seperti pengurus keuangan, menjadi penghubung, mengaur perbekalan logistic, tugas kepalang merahan, yaitu merawat dan mengobati pejuang, bahkan mencari senjata (Nurliana, 1986:2).

Kalau ada pihak yang mengatakan bahwa perempuan Bali masih terbelakang dibandingkan laki-laki di bidang pendidikan, karier, dan dunia politik tentu sulit dibantah. Fakta dan data yang ada di masyrakat mendukung bahwa pendapat tersebut itu benar, namun kalau ada yang mengatakan bahwa perempaun Bali bersifat pasif, nrimo, atau berpangku tangan tanpa 
memperjuangkan nasibnyaatau nasib kaumnya dalam kehidupan sosial tentulah hal tersebut keliru. Bukti tertulis menunjukkan bahwa perempuan Bali bahkan sudak aktif berbicara sejak zaman colonial untuk memperjuangkan harkat dan martabat kaumnya. Namun kalo dilihat secara universal pada saat ini tampaknya masih ada kesenjangan gender dalam hal angka pastisipasi sekolah dan angka pasrtisifasi dalam dunia politik masih rendah.

Kemajuan ilmu pengetahuan yang berkembang sangat pesat menuntut tersedianya sumber daya manusia yang mampu menyesuaikan diri dan mampu menjawab tantangan yang muncul di era globalisasi. Salah satu cara untuk mengembangkan masalah tersebut adalah dengan mengembangkan sumber daya manusia yang berkualitas. Lingkungan utama bagi manusia untuk mengembangkan diri adalah lingkungan keluarga, yakni pada usia dini, yaitu sejak dalam kandungan sudah dididikoleh ibunya untuk menjadi anak yang berkualitas. Hubungan antara anak dan keluarganya sangat erat terutama dengan ibu yang memberikan kebutuhan anak, seperti menyusui, memberi makan, memandikan, dan lain-lain. Pemenuhan akan kebutuhan tersebut menyebabkan anak-anak merasa mendapat perlindungan yang selanjutnya akan menimbulkan perasaan aman pada anak. Demikian pula hubungan antara anak dengan ayahnya merupakan faktor penting. Hal itu disebabkan karena figure seorang ayah diperlukan dalam mengembangkan anak sehingga nantinya anak mempunyai kepribadian yang utuh.

Melalui hubungan yang ermat antara anak dan ibunya akan mengakibatkan si anak mendapat pendidikan. Pendidikan tersebut dapat berbentuk penanaman kebiasaan yang sehat dan baik, penanaman dan pengembangan disiplin diri, control emosi, inisiatif dan kreativitas, serta nilai sosial moral dan spiritual. Pendidikan yang diterima anak tersebut selanjutnya akan berkembang membuat anak menjadi manusia yang berkepribadian utuh. Kegagalan dalam menempatkan pondasi yang diperlukan bagi perkembangan anak pada masa-masa selanjutnya akan menyebabkan upaya untuk menjadikan summber daya manusia menjadi gagal. Sehingga dapat dikatakan bahwa keluarga mempunyai peranan yang sangat penting didalam pemberian pendidikan politik kepada anak-anaknya.

\section{B. Cara-cara Pendidikan Politik Konvensional}

Cara pendidikan politik yang lazim diberikan oleh orang tua terhadap anak-anak mereka ialah dengan ccara menyekolahkan anak-anaknya kesekolah formal sejak taman kanak-kanak, sekolah dasar, sekolah menengah pertama, sekolah menengah atas, dan bahkan sampai pada perguruan tinggi. Melalui pendidikan sekolah anak-anak akan mendapatkan perkembangan ilmu pengetahuan dan memahami arti penting pendidikan dalam menghadapi pesatnya kemajuan nteknologi. Sumber daya manusia yang mempunyai pendidikan serta keterampilan adalah sangat penting artinya dapat masuk kepasqar kerja dan bersaing di dalamnya.

Pendidikan sekolah sebagai sarana yang memungkinkan perempuan bisa berdiri sama tinggi dengan laki-laki. Disamping itu, melalui sekolah aspek kognitif perempuan akan terbuka, intelektualnya akan diasah sehingga dapat berpikir rasional, bisa mewujudkan potensi, dan kreativitasnya, memiliki motivasi untuk maju dan meraih prestasi, dan berkarier serta memperloeh martabat seperti yang dicapai laki-laki.

Kedudukan anak laki-laki dalam Masyarakat di Bali adalah sebagai pewaris dan penerus keturunan atau keluarga. Sehingga beranjak dari realitas ini, laki-laki dalam kehidupan masyarakat di bali mendapatkan otoritas tunggal yang menguasai seperangkat hak dan kewenangan, baik dalam kehidupan keluarga maupun dalam aktivitas kesehariannya sebagai warga desa adat.

Diprioritaskannya anak laki-laki dalam keluarga di Bali, yakni sangat berkaitan dengan sistem pewarisan yang dianut oleh masyarakat di Bali, yaitu 
menganut sistem pewarisan patriarkhi. Artinya, yang menjadi ahli waris adalah anak laki-laki atau keluarga dari pihak laki-laki, Sedangkan perempuan tidak berhak menjadi ahli waris. Yudana (1990) mengatakan bahwa sistem kekerabatan di bali menganut sistem kekerabatan patrilineal yang direfleksikan dengan konsep Purusa atau batang lempeng yakni hubungan kekerabatan vertical ke atas dank e bawah berdasarkan garis laki-laki. Dengan demikian, maka perempuan akan menerima waris ayahnya sepanjang mereka belum menikah atau berumah tangga. Harta yang diberikan oleh orang tua kepada anak perempuannya yang sudah menikah bukanlah berupa warisan, tetapi berupa bekal hidup agar anaknya di keluarga suaminya dapat hidup secara layak sebagai sebuah keluarga baru.

Penghargaan yang begitu tinggi terhadap keberadaan anak laki-laki menimbulkan implikasi bahwa perempuan dipandang rendah kedudukannya dibandingkan laki-laki. Artinya eksistensi perempuan senantiasa diposisikan dan dipandang lebih rendah dari kaum laki-laki. Deengan demikian, maka kehidupan keluarga dan desa adat telah mendukung timbuh dan berkembangnya marjinalisasi kepada kaum perempuan oleh kaum lakilaki. Implikasi kondisi ini juga bermuara pada pemillahan kepemikikan dan kewenangan berbagai sector public cendrung didominasi oleh kaum laki-laki, sementara kaum perempuan hanya menjalankan sector domestic. Dominasi kaum laki-laki bukan hanya dalam bidang public saja, melainkan sampai kepada soal-soal yang sangat pribadi sehingga perjuangan perempuan untuk menghapus sub ordinasi bukan hanya di luar rumah melainkan juga harus dimulai dari dalam rumah (Jangger dalam Suryanto, 2000;435).

Selain hal tersebut di atas, cara-cara pendidikan politik konvensional juga dilakukan oleh orang tua atau keluarga dengan cara pemberian hukuman. Pemberian hukuman adalah cara yang umumnya dilaksanakan untuperilaku-perilaku yang takadaptif, seperti perilaku destruktif terhadap diri sendiri ataupun terhadap lingkungan, dan perilaku-perilaku negative lain yang terus menerus mengganggau fungsi adaptif seseorang atau orang lain di sekitarnya. Hukuman adalah suatu cara pemberian stimulus yang mengikuti suatu perilaku mengurangi kemungkinan berulangnya perilaku tersebbut. Bila bentakan ibu menghentikan berulangnya perilaku rewel anak maka bentakan tersebut adalah hukuman. Bila bentakan ini menimbulkan perilaku rewel berulang maka bentakan ini adalah pengukuhan. Pengaruh negative yang timbul jika orang tua menggunakan hukuman badan yang tidak konsiten terhadap anak adalah kenakalan remaja. Dalam hal ini, hukuman pun dapat memicu kenakalan remaja jika orang tua memberikan hukuman yang kurang tepat kepada anak. Hukuman yang ditekankan dari segi hukuman dan bukan tujuannya, maka oleh anak tidak akan dihayati sebagai bantuan, tetapi sebagai penyiksaan (Shochib, 1998:8).

\section{Cara-cara Pendidikan Politik Maju}

Sudah menjadi tanggung jawab orang tua dan pemerintah untuk mewujudkan program wajib belajar Sembilan tahun. Untuk memenuhi kewajiban tersebut Pemerintah provinsi Bali telah bekerjasama dengan semua Kabupaten-Kota di Bali melalui Dinas Pendidikan dan Kebudayaan telah menyediakan sarana dan prasarana pendidikan bagi masyarakat Bali. Sekolah yang didirikan muali dari taman kanak-kanak sampai dengan perguruan tinggi. Sehingga seluruh orang tua wajib untuk menyekolahkan anak-anaknya di lembaga pendidikan formal, minimum selama Sembilan tahun.

Sehubungan dengan hal tersebut di atas, maka pendidikan nonformal yang diberikan orang tua kepada anak perempuannya di rumah merupakan cara pendidikan politik yang juga dilaksanakan oleh keluarga di Bali, selain menyekolahkan anak perempuannya ke sekolah formal. Keluarga merupakan salah satu lembaga yang mengemban tugasdan tanggung jawab dalam pencapaian tujuan pendidikan umum. 
Tujuan esensial pendidikan umum adalah mengupayakan sukjek didik menjadi pribadi yang utuh dan terintegrasi. Untuk mencapai tujuan ini, tugas dan tanggung jawab keluarga (orang tua0 adalah menciptakan kondisi yang membuat iklim yang dapat dihayati anak-anak untuk memperdalam dan memperluas makna-makna esensial (shochib, 1998:2).

Dilihat dari pola asuh dalam keluarga di Bali sekarang sudah mulai tidak lagi orang tua membeda-bedakan anak laki-laki dan perempuan di dalam menuntut pendidikan. Namun melalui pengamatan dilapangan masih ada beberapa orang tua yang memberlakukan atau memprioritaskan anak laki-lakinya di dalam pendidikan. Hal ini terjadi karena masyarakat di Bali masih menganut sitem kekerabatan parilineal yang senantiasa berpihak pada kaum laki-laki dalam segala bidang dimensinya (Adiwikara, 2000).

Secara biologis anak laki-laki dan perempuan berbeda, laki-laki memiliki penis, jakun, dan dapat memproduksi sperma, sedangkan perempuan memiliki rahim, buah dada, memproduksi indung telur, dan air susu. Apa yang dimiliki laki-laki tidak dimiliki perempuan, begitu pula sebaliknya. Kodrat fisik yang berbeda tersebut berpengaruh pada kondisi psikis masingmasing. Perempuan dengan Kodrat fisik untuk bisa melahirkan berakibat pada perkembangan perangai psikologisnya yang membutuhkan untuk mengasuh anak yang dilahirkan, seperti perangai keibuan yang menuntut sikap halus, penyabar, dan kasih sayang. Dengan kodrat fisik laki-laki yang dimilikinya, yakni penis dan produksi sperma yang dapat membuahi sel telur dengan jumlah yang banyak dalam waktu relative singkat, dipandang merepresentasikan fisik laki-laki yang kuat. Dengan kodrat fisik dan psikologis tersebut laki-laki dikontruksikan berperan disektor public yang keras sekaligus memberikan perlindungan pada pihak yang lemah, yaitu perempuan (Budiman, 1985:14).

Jika melihat peran keluarga sangat penting dan paling utama, dimana peran orang tua di zaman modern ini harus juga mampu mendorong anak-anaknya untuk melaksanakan berbagai kegiatan yang membuat masa depan meraka menjadi cerah. Dimana orang tua berperan selain sudah menyekolahkan ke sekolah formal seperti yang telah di ungkapkan di atas, di jaman era globalisasi telah banyak ditemui para orang tua mendorong anak perempuannya untuk mengikuti pelajaran tambahan atau les berbagai keterampilan. Cara ini pada hakikatnya juga adalah merupakan salah satu cara orang tua dalam memberikan pendidikan politik pada anak perempuan di Bali. Kursus keterampilan ini tentunya akan sanagt bermanfaat bagi anak perempuan yang juga merupakan salah satu dasar penting yang harus dikuasai oleh individu selain keterampilan atau kemampuan membaca yang diperoleh dalam pendidikan formal disekolah.

Disamping itu, para orang tua di zama era globalisasi juga mendorong anak perempuannya untuk ikut aktif di dalam berorganisasi dalam berbagai kegiatan baik disekolah maupun diluar sekolah yang merupakan salah satu cara orang tua dalam memberikan pendidikan politik pada anak perempuannya. Di antara kegiatan-kegiatan tersebut menjadi pengurus organisasi sekolah, pramuka, palang merah remaja, ikut partai politik. Para orang tua di Bali sekarang telah banyak mendorong anak perempuannya untuk beraktivitas dalam kegiatan-kegiatan seperti di sebut di atas, hal ini sesuai dengan pendapat John Naisbritt dan Patricia Arbune (dalam Wardani, 1999:101) yang menyatakan bahwa pada akhir abad ke -20 ada beberapa kemajuan yang sangat menarik di Negara-negara berkembang. Salah satu diantaranya adalah adanya kebangkitan gerakan perempuan yang mampu menciptakan ruang yang cukup aktif untuk mensosialisasikan program pemberdayaan dan kesetaraan genser. Pada tingkat praktis, kecendrungan yang dikatakan menarik tersebut terbukti dengan semakin terjaminnya hak politik bagi kaum perempuan di berbagai tempat didunia. Hamper 95\% Negara-negara di dunia telah 
menjamin dua hak demokratik warga Negara, yakni hak memilih (right to vote0 dan hak untuk mencalonkan diri dalam pemilihan umum 9right to stand of election). Hal tersebut dapat dibuktikan dalam dunia perpolitikan Indonesia pada tanggal 19 Juli 2001 adalah merupakan salah satu tonggak penting dalam sejarah politik perempuan di Parlemen Indonesia, pada salah satu ruangan di Gedung DPR/MPR telah diresmikan senbuah kelompok kerja atau forum dengan nama Kaukus Perempuan Pilitik. Mereka beranggotakan perempuan anggota Parlemen Indonesia yang bertujuan untuk meningkatkan peran dari perempuan di dalam dunia politik untuk memperjuangkan serta menegakkan hak-hak politik perempuan Indonesia.

\section{Fungsi Pendidikan Politik Perempuan Bali}

Dengan kata lain, masyarakat merupakan sistem sosial yang terdiri atas bagian-bagian atau elemen-elemen yang berkaitan dan saling menyatu dalam keseimbangan. Perubahan yang terjadi pada satu bagian akan membawa perubahan pula terhadap bagian yang lain. Asumsi dasarnya, adalah bahwa setiap struktur dalam sistem sosial adan fungsional terhadap yang lain (Ritzer, 1992:25).

Dimana setiap tindakan manusia berfungsi untuk kelangsungan kehidupan mereka, sekalipun integrasi tidak pernah dicapai dengan sempurna, tetapi secara fundamental akan tetap bergerak kea rah equilibrium yang bersifat dinamis, sehingga pada akhirnya akan dicapai suatu consensus di antara masyarakat (Nasikum, 1999:11). Pendidkian politik bagi perempuan bali di lingkungan keluarga merupakan wadah dalam menuju terwujudnya partisipasi perempuan dalam pembangunan. Dalam hal ini pemberdayaan perempuan mempunyai fungsi yang sangat besar bagi pembangunan pemberdayaan perempuan.

\section{1). Fungsi Ekonomi}

Dalam era otonomi daerah peranan perempuan perlu lebih ditingkatkan, terlebih dalam era reformasi, terutama dalam bidang ekonomi. Penduduk, termasuk didalamnya kaum perempuan adalah salah satu modal dasar pembangunan nasional. Tanpa mengikutsertakan perempuan dalam proses pembangunan bangsa dan Negara itu berarti lebih dari setengah jumlah penduduk Indonesia tdak tertampung aspirasinya dalam pembangunan bangsa dan Negara khususnya pembangunan di bidang ekonomi.

Peranan perempuan dalam pembangunanekonomi terutama dalam masa Orde Baru cenderung memanfaatkan pekerja perempuan sebagai alat reproduksi murah dalam upaya menarik investasi untuk memicu pertumbuhan ekonomi. Upah murah pekerja perempuan dipakai sebagai salah satu alat promosi untuk mencari investasi. Investasi meningkat diikuti dengan peningkatan keterlibatan perempuan di sector public upahan, baik dalam maupun luar negeri. Investasi telah berhasil menaikkan nilai ekspor sehingga dapat memicu pertumbuhan ekonomi.

Ketimpangan peran perempuan dan laki-laki dalam pembangunan bukan bersumber pada masalah perempuan (kualitas rendah), tetapi bersumber dari luar diri mereka (masyarakat). Pandangan bahwa kualitas sumber daya perempuan kurang berkualitas (konstruksi sosial) dibandingkan laki-laki sehingga meletakkan perempuan sebagai alat produksi yang dapat dimanfaatkan dan dapat dibayar murah dalam proses pembangunan. Oleh karena itu, maka untuk dapat bersaing secara terbuka di pasar kerja perempuan perlu dibekali dengan pendidikan politik dan keterampilan sesuai dengan kebutuhan pasar kerja. Pemberdayaan perempuan mungkin dapat mencapai sasaran apabila akses pada informasi, peluang kerja dan kemampuan bersaing di pasar kerja ditingkatkan.

Program tersebut di atas dapat tercapai apabila idiologi gender yang dikontruksi sejak lahir dapat dihilangkan. Program dekonstruksi idiologi gender perlu terus dilancarkan dalam berbagai bidang. Sasarannya tidak hanya kaum perempuan tetapi jugalaki-laki. Tanpa upaya ini bisa jadi 
perencanaan, kebijakan, dan program pembangunan tetap cendrung bias gender. Oleh karena itu, maka dalam upaya pemberdayaan perempuan dengan pendekatan kesejahteraan melainkan menjawab masalah kebutuhan strategis kaum perempuan. Artinya pemberdayaan kaum perempuandengan melawan dan menghancurkan hegemoni laki-laki, disamping mengembangkan wacana untuk melawan (Dekontruksi) idiologi gender yang telah mendarah daging dalam keyakinan, baik terhadap perempuan maupun laki-laki.

\section{2). Membentuk Disiplin Diri dan Kemandirian}

Dalam membentuk disiplin diri dan kemandirian pada anak, orang tua dapat merealisasikan dengan cara menciptakan situasi dan kondisi yang dihayati oleh anakanak agar memiliki dasar-dasar dalam mengembangkan disiplin diri dan kemandirian. Pribadi yang memiliki dasardasar dan mampu mengembangkan disiplin diri, berarti memiliki keteraturan diri berdasarkan acuan nilai moral. Disiplin diri dan kemandirian dibangun dari asimilasi dan pembangunan nilai-nilai moral untuk diinternalisasikan oleh subjek didik sebagai dasar untuk mengarahkan perilakunya. Untuk mengupayakan hal itu orang tua dituntut untuk memiliki keterampilan sebagai pedagogis dan proses pembelajaran pada tataran tinggi (Shochib, 1998:2).

Menurut Duvall (dalam Shochib, 1998:19) menyatakan bahwa dalam membentuk disiplin diri dan kemandirian pada anak seperti yang diharapkan oleh para orang tua di Bali, yakni perlu diupaya orang tua untuk menciptakan situasi dan kondisi yang dapat mengundang anak berdialog dengan mereka sejak usia dini agar anak menyadari bahwa moral adalah sebagai landasan keteraturan disiplin dirinya. Orang tua berkewajiban meletakkan dasar-dasar disiplin diri kepada anak, kemudian bersama sekolah dan masyarakat dikembangkanlah disiplin diri itu. Dengan perkataan lain,setiap tindakan pendidikan yang diupayakan orang tua harus senantiasa dipertautkan dengan dunia anak. Dengan demikian, maka setiap peristiwa yang terjadi tidak boleh dilihat sepihak dari sudut pandang pendidik, tetapi harus dipandang sebagai pertemuan antara pendidik dengan anak didik dalam situasi pendidikan. Disamping itu orang tua perlu mendasarkan diri pada sikap saling mempercayai dalam membantu anak agar memiliki dan mengembangkan dasar-dsara disiplin diri. Atas sikap saling mempercayai ini, maka mereka akan memiliki kebebasan berakreativtas guna mengembangkan diri masing-masing.

\section{3). Memperluas Tanggung jawab}

Pendidikan politik sejak dini pada anak perempuan di dalam keluarga selain mempunyai fungsi ekonomi dan disiplin diri juga mempunyai fungsi untuk memperluas tanggung jawab. Bila setiap anggota keluarga ditanyakan pendapatnya mengenai pendidikan non formal pada anak perempuan, maka dapat dipastikan bahwa hamper semua jawabannya bahwa pendidikan non formal perlu diberikan kepada anak perempuan, oleh karena dengan diberikannya pendidikan non formal, maka akan belajar menjadi anak yang bertanggung jawab. Pola asuh orang tua terhadap anak sebagai upaya orang tua dalam meletakkan dasar-dasar tanggung jawab kepada anak dan membantu mengembangkannya sehingga anak memiliki rasa tanggung jawab.

Orang tua sebagai coordinator keluarga harus berperilaku positif. Selanjutnya, diantara anggota keluarga saling mendengarkan jika berbicara bersama melalui teladan dan dorongan orang tua setiap masalah yang dihadapi dan diupayakan untuk dipecahkan. Jika didalam keluarga telah terjadi keseimbangan maka seluruh keluarga akan merasa nyaman, setiap anggota keluarga akan memiliki rasa tanggung jawab dan dapat dipercaya, saling membantu di antara anggota keluarga dalam mengembangkan diri, maka adanya rasa kebersamaan dan komunikasi dialogis. Tanggung jawab dan kepercayaan orang tua yang dirasakan oleh anak akan menjadi dasar peniruan untuk berperilaku. 


\section{4). Sosial dan Pelayanan Publik}

Salah satu fungsi pendidikan politik pada perempuan dalam keluarga adalah fungsi bidang sosial dan pelayanan public. Kedudukan perempuan di masyarakat yang masih dianggap subordinat, yakni dsebabkan adanya konstruksi sosial budaya yang meletakkan peran laki-laki dan perempuan secara berbeda-beda yang didasarkan pada pemhaman perbedaan biologis dan fsiologis antara laki-laki dan perempuan. Idiologi gender yang berkembang di masyarakat teleh menentukan bahwa rumah tangga atau ranah domestic adalah duniannya perempuan, sementara ranah public adalah dunianya lakilaki. Ketidak adilan gender seperti itu mengakibatkan keteimpangan gender pada aspek kehidupan masyarakat, salah satunya adalah pada bidang sosial dan pelayanan publik.

Ada beberapa faktor yang menghambat perempuan untuk mengaktualisasikan dirinya di dalam sector public. Faktor tersebut antara lain adalah faktor internal yang datanngnya dari dalam diri perempuan itu sendiri. Artinya, bahwa perempuan karena dipengaruhi naluri keibuannya, ia memilih untuk tinggal di rumah mengurus pekerjaan rumah tangga dan keluarga. Pekerjaan mengurus rumah tangga menjadi pilihannya sehingga ia tidak mempunyai keinginan untuk melakukan kerja produktif.

Sementara faktor eksternal yang dapat mempengaruhi perempuan untuk tampil dalam sector public adalah sosial budaya, terutama dalam bentuk gender stereotif yang berkembang dimasyarakat. Perempuan dipandang sebagai mahkluk yang pasif lemah, dan tergantung. Sebaliknya lakilaki dinilai sebagai mahkluk yang aktif, kuat, cerdas, dan mandiri. Selain itu ada pandangan yang dikotomistis antara peran laki-laki dan perempuan. Dalam hal ini sudah seharusnya perempuan menjalankan peran domestic dan laki-laki peran publik. Dikotomis peran seperti itu akan membawa implikasi yang sangat luas terhadap keberadaan perempuandi sector public, seperti dalam hal peningkatan profesionalisme kerja, jabatan dan upah. Pemilihan peran domestic dan public tersebut disosialisasikan sejak dini di lingkungan keluarga (dzuhayatin, dalam Muthaliin, 2001:29).

\section{5). Memperluas Wawasan}

Para orang tua dizaman era globalisasi telah memberikan kesempatan kepada anak perempuannya dalam sekolah formal dan non formal, mendorong anak untuk kursus, dan aktif berorganisasi, maka anak perempuan akan memiliki bekal pengetahuan yang handal, dan perempuan tidak akan mempunyai wawasan yang lebih sempit dibandingkan laki-laki. Dengan mempunyai wawasan yang luas, perempuan tidak akan kesulitan dalam menghadapi era globalisasi ke depan. Di dalam menghadapi persaingan global, kaum perempuan telah berupaya mengembangkan diri dan meningkatkan kualitas diri melalui pendidikan dan keterampilan. Terlebih lagi dalam menghadapi era perdagangan bebas, peningkatan kualitas sumber daya manusia menjadi suatu keharusan. Menurut Kepala Biro Bina Kesejahteraan dan Pemberdayaan Perempuan (BKPP) Sekretariat Daerah Provinsi Bali Luh Putu Haryani (dalam Bali Post, 1 Juni 2005) menyatakan bahwa:

"Perempuan harus diberikan kesempatan seluas-luasnya untuk meningkatkan kemampuan diri. Pendidikanlah yang dapat dijadikan 'bekal' oleh kaum perempuan ketika nanti mereka berada di lingkungan keluarga suami dan berkiprah dalam pembangunan".

Hal yang sama juga dikatakan oleh Katua Parisadha Bali I Gusti Ngurah Sudiana (Bali Post, 1 Juni 2005) menyatakan bahwa jika kesempatan diberikan perempuan untuk memiliki kemampuan yang sama dengan kaum laki-laki. Dalam Nitisastra disebutkan bahwa kekuatan perempuan jauh lebih besar dibandingkan laki-laki. Bahkan perempuan memiliki kekuatan delapan sedangkan lakilaki satu. Hal ini berarti jika potensi yang dimiliki perempuan dikembangkan akan jauh hebat dari pada laki-laki. 


\section{E. Membuktikan Kesetaraan Kemampuan}

Kesetaraan dan keadilan gender diartikan sebagai suatu kondisi yang adil (equity) dan setara (equality) dalam hubungan kerja sama antara laki-laki dan perempuan. Kesetaraan dalam hal ini tidak berarti kesamaan secara mutlak. Oleh karena laki-laki dan perempuan tidak bisa disamakan dalam segala hal mengingat kedua manusia ini dilahirkan dengn jenis kelamin yang berbeda sehingga berbagai hal diberlakukan berbeda tetapi tidak merugikan dalah satu pihak (baik laki-laki maupun perempuan). Namun, ada juga perlakuan berbeda yng merugikan salah satu pihak, perlakuan seperti inilah dinamakan tidak adil gender. Secara normative baik dalam Undang-Undang dasar 1945 maupun dalam Garis_garis besar Haluan Negara telah tercantum bahwa laki-laki maupun perempuan mempunyai hak dan kewajiban yanag sama dalam segala aspek pembangunan. Di samping itu, Negara kita juga telah meratifikasi (mengesahkan) Konvensi Penghapusan segala bentuk diskriminasi terhadap perempuan yang telah tertuang dalam UU Nomor 74 Tahun 1984.

Konsep kesetaraan memang merupakan suatu konsep yang sangat rumit dan controversial. Ada yang mengatakan bahwa kesetaraan adalah persamaan dalm hak dan kewajiban, yang tentunya masih belum jelas artinya. Ada juga yang mengartikan dengan konsep mitra kejejajaran antara laki-laki dan perempuan yang juga masih belum jelas artinya. Sering juga diartikan bahwa perempuan mempunyai hak yang sama dengan laki-laki dalam aktualisasi diri, tetapi harus sesuai dengan kodratnya masing-masing. Walaupun secara biologis perempuan dan laki-laki berbeda, kemampuan yang dimiliki oleh perempuan secara fisik dapat dikatakan berbeda tetapi secara non fisik kemampuan perempuan dapat dikatakan setara dengan laki-laki.

Dengan diberikannya kesempatan kepada perempuan maka perempuan tidak saja berkecimpung dalam peran reproduktif, dan domestic, tetapi juga dalam produktif.
Peran produktif adalah peran yang dilaksanakan oleh laki-laki ataupun perempuan, berkaitan dengan pemeliharaan sumber daya manusia dan pekerjaan urusan rumah tangga. Peran produktif yang dilaksanakan laki-laki dan perempuan, tidak menghasilkan pendapatan atau nafkah secara langsung, tetapi memberikan kesempatan bagi anggota rumah tangga yang lain untuk memanfaatkan peluang yang ada dalam pekerjaan produktif. Peran produktif ini lebih banyak dilakukan oleh kaum perempuan dari pada laki-laki. Keadaan ini tidak terlepas dari norma dan nilai sosial budaya yang masih berlaku pada masyarakat di Bali, yang menganggap bahwa perempuan lebih pantas memainkan peran di sector domestic 9peran reproduktif dan laki-laki lebih pantas memainkan peran disektor publik.

Keragaman biologis yang berdampak pada diferensiasi peran laki-laki dan perempuan dapat diterima dalam masyarakat Bali pada umumnya. Di samping itu, pembagian peran ini sudah sesuai dengan pembagian peran dalam masyarakat bali, masing-masing jenis kelamin bertindak untuk saling melengkapi, hidup harmonis, dan memunyai tujuan hidup bersama. Diferensiasi ini ditujukan agar mekanisme untuk saling melengkapi sehingga tercipta hubungan kesatuan harmonis seperti simbul Purusa dan Pradhana dalam agama Hindu, mereka setara tetapi berbeda.

Kesetaraan dalam keberagaman dapat tercapai kalau keragaman yang ada pada manusia dapat dihormati sebagai mahkluk hidup, tidak lebih dan tidak kurang dari yang lainnya, semata-mata berbeda dalam kemampuan, bakat, dan kodratnya. Jika kesetaraan dalam keberagaman ingin diciptakan, maka diperlukan sebuah struktur masyarakat yang melandasinya. Keberagaman peran berarti pula keberagaman struktural, atau adanya masyarakat berstruktur. Dengan demikian, maka kesetaraan antara laki-laki dan perempuan dapat diwujudkan di dalam masyarakat Bali, jika perempuan diberikan kesempatan untuk membuktikan kemampuannya di dalam segala bidang. 


\section{KESIMPULAN}

Berdasarkan paparan di atas, maka dapat dijelakan bahwasannya secara biologis antara laki-laki dan permpuan mempunyai perbedaan. Namun kebudayaan menafsirkan perbedaan biologis ini menjadi seperangkat tuntutan sosial tentang kepantasan dalam berperilaku, masyarakat menyerahkan tanggung jawab perawatan anak kepada perempuan, sedangkan tugas mencari nafkah diberikan kepada laki-laki. Kesetaqraan gender dalam keluarga akan memberikan kesempatan kepada perempuan untuk terlibat langsung dalam segala aspek kehidupan, khususnya dalam kehidupan keluarga karena setiap keputusan tersebut juga menyangkut kepentingan perempuan. Dari hasil pembahasan di atas maka dapat diambil suatu kesimpulan bahwa pendidikan politik perempuan Bali menuju terwujudnya kesetaraan gender dapat dibedakan menjadi bentuk yang dilakukan oleh keluarga pada masyarakat di Bali yaitu dengan cara-cara pendidikan konvensional dengan cara: (1) sekolah foemal; (2) anak laki-laki lebih diprioritaskan; (3) hukuman; (4) anak harus mendengarkan orang tua. Serta keluarga juga memberikan anak-anaknya pendidikan politik maju dengan cara menyekolahkan anaknya di sekolah formal, nonformal, anak laki-laki dan perempuan tidak dibedabedakan, mendorong anak untuk ikut kursus keterampilan, dan mendorong anaknya untuk ikut dalam organisasi.

Fungsi pendidikan politik bagi perempuan bali menuju terwujudnya kesetaraan gender di Bali adalah mencakup adanya fungsi ekonomi, fungsi membentuk kemandirian, fungsi memperluas tanggung jawab, fungsi sosial dan pelayanan public, fungsi memperluas wawasan, fungsi membuktikan kesetaraan kemampuan. Secara umum, setiap subsistem dalam pendidikan politik perempuan Bali menuju terwujudnya kesetaraan gender di Bali dapat dikatakan sudah berlangsung secara fungsional, hal ini berarti telah terjadi keseimbangan-keseimbangan yang membentuk struktur dalam pendidikan politik bagi perempuan Bali menuju terwujudnya kesetaraan gender yang dilakukan oleh keluarga, masyarakat, dan pemerintah dalam hal ini pengambilan kebijakan. Hal ini dapat disimpulkan bahwa politik perempuan telah berjalan dengan relative baik meskipun harus diakui masih ada kelemahan-kelemahannya.

\section{Daftar Rujukan}

Adiwikara, S. 2000. Sosiologi Kontemporer Pemahaman Beberapa Grand Theorys (Teori-teori Besar Sosiologi). Jakarta: PT Remaja.

Budiman, Arief. 1985. Pembagian Kerja Secara Seksual Sebuah Pembahasan Sosiologis tentang Peran Wanita di masyarakat. Jakarta: PT. Gramedia.

Emiyati, Sri. 2001. Akses dan Kontrol Perempuan terhadap Hak-hak Politik pada Pemilu 1999. Di Medan'. Jurnal Pemberdayaan Perempuan. Volume 1, Nomor 1, November 2001.

Muthaliin, Abmad. 2001. Bias Gender dalam Pendidikan. Surakarta; Universitas Muhammadiyah.

Nasikum. 1999. Sistem Siosial Indonesia. Jakarta: PT Raja Grafindo Persada.

Nurliana, dkk. 1986. Peranan wanita Indonesia di Masa Perang Kemerdekaan 1945-1950. Jakarta: Proyek IDSN.

Soetjipto, Mi. 2000. Perempuan dan Politik Indonesia. Dalam Sita Van Bemmelen, dkk. (penyunting). Benih Bertumbuh. Jakarta:Panitia Peringatan Ultah Thu T.o thromi ke-70 Tahun, hal. 446-461.

Shochib, Moh. 1998. Pola asuh Orang Tua dalam Membentuk Anak Mengembangkan Disiplin Diri. Jakarta: PT. Rineka Cipta.

Suci, A. (2017). Penjaminan mutu perguruan tinggi: Dilema politik organisasi dan urgensi penggunaan profesional eksternal. Jurnal Penjaminan Mutu, 3(2), 215-222. 
Suryanef, Budi. 2001. Pengetahuan dan Sikap Wanitaterhadap Kepolitikan Orde Baru. Jurnal Pemberdayaan Perempuan. Volume I. Nomor 1, November.

Suryanto. Isbodroini. 2000. Idiologi Patriarki yang Tercermin dalam Berbagai struktur Masyarakat. Dalam: sita Van Bemmelen, dick (penyunting). Benih Bertumbuh. Jakarta: Panitia Ultah Thu T.O thromi ke-70 Tahun, hal. 434443.

Wardani, Sri Budi Eko. 1999. Aspirasi Perempuan Anggota Parlemen Terhadap Pemberdayaan Politik Perempuan. Jakarta: Yayasan Jurnal Perempuan.

Yudana, I G. N. 1990. Identifikasi Awig-awig desa Adat Kuno di Kabupaten Buleleng Daerah Tingkat II Buleleng. Denpasar: Universitas Udayana. 